\title{
How do the Banking Systems of High Income Countries differ from others?
}

\author{
http://doi.org/10.21272/fmir.5(1).42-49.2021
}

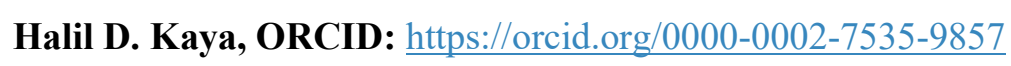

Professor of Finance, Department of Accounting and Finance, College of Business and Technology, Northeastern State University, USA

\begin{abstract}
In this study, first we look at the relation between countries' income levels and their banking systems. What are the differences between richer countries and other countries in terms of their banking systems? Then, we look at how OECD membership affects the banking system of a country. When we compare High-Income countries to Middle- and Low-Income countries, we find that workers' remittances are much higher in Lowand Middle-income countries. The banking industries are much more concentrated in High-Income countries. Bank deposits are also significantly higher in these countries. The banking systems in these countries have more risk compared to their counterparts in other countries. Non-resident banks are more active in HighIncome countries. Also, there is more interest in offshore accounts and the banks are more engaged in international transactions. When we compare high-income OECD-member countries to high-income NonOECD-member countries, we find that the banking industries in high-income Non-OECD-member countries are much more concentrated when compared to their counterparts in High-Income OECD countries. In HighIncome Non-OECD countries, non-resident banks are more active and there is more interest in offshore accounts. On the other hand, bank deposits are higher in High-Income OECD countries. But, the banks in these countries are in greater risk compared to the banks in Non-OECD countries (i.e. liquid liabilities are higher). We conclude that policymakers need to consider OECD membership and income level as determinants of a country's banking system.
\end{abstract}

Keywords: banking system, financial system, OECD, income level.

JEL Classification: G20, G21.

Cite as: Kaya, H.D. (2021). How do the Banking Systems of High Income Countries differ from others? Financial Markets, Institutions and Risks, 5(1), 42-49. http://doi.org/10.21272/fmir.5(1).42-49.2021

Received: 28 January 2021

Accepted: 1 March 2021

Published: 30 March 2021

Copyright: (C) 2021 by the author. Licensee Sumy State University, Ukraine. This article is an open access article distributed under the terms and conditions of the Creative Commons Attribution (CC BY) license (https://creativecommons.org/licenses/by/4.0/)

\section{Introduction}

In this paper, we examine the relation between countries' income levels and their banking system. More specifically, we compare the values of nine "banking system" variables across high-income countries versus middle and low income countries.

World Bank's Global Financial Development Database has data on 203 countries' banking systems. We use the nine "banking system" variables included in that database. These variables are "Bank concentration", "Bank deposits to GDP", "5-bank asset concentration", "Liquid liabilities", "Loans from non-resident banks (net) to GDP", "Loans from non-resident banks (amounts outstanding) to GDP", "Offshore bank deposits to domestic bank deposits", "Remittance inflows to GDP", and "Consolidated foreign claims of BIS-reporting banks to GDP”.

The previous papers that examine the relationship between financial development (including the banking system) and economic growth have mixed results. While a good portion of these studies (Bagehot (1873), Hicks (1969), and King and Levine (1993)) contend that financial development leads to economic development, some studies contend that economic development leads to financial development. 
There are also papers that compare the banking systems of developed and developing countries. Most of these studies compare bank concentration (i.e.. bank competition) across developed versus developing countries. Here, again, the findings are mixed. While some of the studies support the view that less competition (i.e. more concentration) has a stabilizing effect on the financial system, others argue that less competition has a destabilizing effect on the financial system.

In this current paper, we focus on nine variables on the banking system. One of these variables is "Bank concentration", so we are hoping to contribute to the discussion on the relation between bank competition and financial stability. Our study goes deeper (i.e. we examine nine variables on banking) and it covers more countries (i.e. 203 countries) when compared to the other studies that compare the banking systems around the world. Our variables cover several different aspects of a banking system including bank concentration, asset concentration, deposits, liabilities, loans, offshore bank deposits, remittances, and foreign claims.

The next section goes over the previous literature. The data and the methodology are detailed in Section 2. We present the results in Section 3. The final section includes our concluding remarks.

\section{Literature Review}

Financial development and Economic Growth. The earlier studies on the topic generally support the view that financial development causes economic growth. Bagehot (1873) makes the first argument on the topic and contend that industrialization in England was positively affected by financial development in the country. More recently, Hicks (1969) supports this view. By examining 80 countries over the 1960-1989 period, King and Levine (1993) show that the financial system promotes economic growth. The authors explain that financial development causes improvements in efficiency and in real per capita GDP, and also increases the rate of physical capital accumulation. Several other papers like Shaw (1973), Pagano (1993), and Fry (1988) also look into the same issue.

On the other hand, a few other papers support the view that economic growth causes financial development. Odhiambo (2008) examines the relationship between financial and economic development in Kenya. The author shows that economic growth causes financial development. The mechanism according to this paper works like this: Economic growth causes savings and savings cause financial development. Ang and McKibbin (2007) support this view. For Malaysia, the authors find a positive relationship between financial depth and economic development. They contend that output growth leads to more financial depth in the long-run.

While these two camps have differing opinions, a few other studies show that the causal relationship between economic growth and financial development is not clear. Arestis and Demetriades (1997) contend that crosscountry regressions may not work well because each country has a different policy regime, institutional structure, and governance. According to this paper, the results significantly vary across countries. Demetriades and Hussein (1996) show that, there is a feedback effect in about half the countries, but still in several countries, economic growth causes financial development. Arestis and Demetriades (1999) also support this view. They show that the causal link between finance and growth depends on the individual countries' circumstances which include the characteristics and operation of their financial institutions and the policies pursued. Levine (1999) first refers to Goldsmith (1969) as a seminal paper and then examine the relationship between financial and economic development. According to Levine (1999), we still do not know the direction of the causality between financial development and economic growth. Klein and Olivei (1999) examine how open capital accounts affect financial depth and economic growth. They find that developed countries with open capital accounts had better economic growth and financial depth when compared to other countries. However, for developing countries, they do not find the same effect. For these countries, opening up the capital account does affect financial depth. Yet there are other papers that simply ignore the impact of finance on economic growth. Lucas (1988) argues that economists exaggerate the impact of finance on growth. Both Stern (1989) and Chandavarkar (1992) ignore the role of the financial system in economic growth as well.

Bank Concentration and Bank Competition in Developed and Developing Countries. While the above mentioned studies focus on the direction of the causality between financial development and economic growth, there are other papers that focus on the banking systems of developed and developing countries. These studies examine bank concentration (i.e. bank competition) across developed versus developing countries.

Duke and Cejnar (2013) contend that the 2008-2009 global crisis has led to more consolidation in the banking systems around the world. Since bank concentration and competition are inversely related, this trend toward more consolidation should have reduced the efficiency of the system (i.e. because of reduced competition). 
Foer and Resnikoff (2014) support this view and argue that the favorable treatment for the so-called "too big to fail" banks in both the United States and the European Union (but especially in the U.S.) was detrimental for banking competition

Is this trend of increased consolidation (i.e. reduced competition) in the banking sector good for the stability of the financial system or is it detrimental to the soundness of the system? There are opposing views on this. While some papers support the view that less competition (i.e. increased bank concentration) stabilizes the financial system, others argue that less competition destabilizes the system.

Using a large sample of both developed and developing countries, Ali, Intissar, and Zeitun (2015) show that bank concentration does not seem to directly affect financial stability. However, when they differentiate between developed and developing nations, they find that bank concentration (i.e. less competition) has a stabilizing effect only for developing countries. Kokkoris (2014) supports this view and argues that high levels of banking competition may lead to more risk taking by banks which would lead to more bank failures.

While the above mentioned papers support the view that less competition is good for financial stability (at least for developing countries), others support the opposing view. Haouat, Moccero, and Navarro (2012) examine the entry of foreign banks in Latin America and find that this trend caused a reduction in credit volatility, which is an evidence of the positive impact of bank competition on stability in developing countries. Feldmann (2006) contends that entry restrictions for foreign banks may have negative consequences (i.e. higher unemployment). Demirguc-Kunt and Detragiache (1998) argue that, especially in developing countries, foreign banks have become more active which is good for financial stability in those countries.

Duke and Cejnar (2013), on the other hand, does not support these two views. According to Duke and Cejnar (2013), competition does not directly support stability. Other factors like financial regulation, consumer protection and good lending practices are also important factors for financial stability.

In this current study, we examine several variables including bank concentration (i.e. competition), five-bank asset concentration, bank deposits, liabilities, activities of non-resident banks, offshore deposits, remittances, and consolidated foreign claims.

\section{Data and Methodology}

In this study, as measures of banking system, we use nine variables. These are listed below with their sources explained in parenthesis. We actually collected the data from World Bank's Global Financial Development Database (GFDD) which has information on access to finance, banking systems, and depth, efficiency, and stability of financial systems in the world. World Bank collected these data from different sources. Here, we show the original source of each variable. All of the variables and their definitions are taken from World Bank's Global Financial Development Database.

Below are the "banking system" measures that we are using in this study as defined in the database:

$>$ "Bank concentration (\%): Assets of three largest commercial banks divided by total commercial banking assets.

$>$ Bank deposits to GDP (\%): The total value of demand, time and saving deposits at domestic deposit money banks/GDP.

$>$ 5-bank asset concentration (\%): Assets of five largest banks divided by total commercial banking assets.

$>$ Liquid liabilities in billions 2000 USD: Absolute value of liquid liabilities in 2000 US dollars.

$>$ Loans from non-resident banks (net) to GDP (\%): Net offshore bank loans/GDP.

$>$ Loans from non-resident banks (amounts out.) to GDP (\%): Outstanding offshore bank loans/GDP.

$>$ Offshore bank deposits to domestic bank deposits (\%): Offshore bank deposits/domestic deposits.

$>$ Remittance inflows to GDP (\%): Workers' remittances and compensation of employees comprise current transfers by migrant workers and wages and salaries earned by nonresident workers.

$>$ Consolidated foreign claims of BIS-reporting banks to GDP (\%): Consolidated for. claims divided by GDP (for the banks that are reporting to BIS)." 
Financial Markets, Institutions and Risks, Volume 5, Issue 1, 2021 ISSN (online) - 2521-1242 ISSN (print) - 2521-1250

In the sample, 31 countries are High-Income OECD countries, 29 countries are High-Income Non-OECD countries, 108 countries are Middle-Income countries, and 35 countries are Low-Income countries. In order to compare the High-Income countries to the Other countries and also to compare the High-Income OECD countries to the High-Income Non-OECD countries, we use the Mann-Whitney-Wilcoxon test in the following section.

\section{Empirical Results}

Table 1-Panel A shows the summary statistics for the High-Income OECD Countries. Table 1-Panel B shows the summary statistics for the High-Income Non-OECD Countries. We are seeing that, in three measures (i.e. "Bank deposits to GDP (\%)", "Liquid liabilities in billions 2000 USD", and "Remittance inflows to GDP (\%)), the High-Income OECD countries have higher values compared to the High-Income Non-OECD countries. In terms of the other six measures (i.e. "Bank concentration (\%)", "5-bank asset concentration (\%)", "Loans from non-resident banks (net) to GDP (\%)", "Loans from non-resident banks (amounts out.) to GDP (\%)", "Offshore bank deposits to domestic bank deposits (\%)", and "Consolidated foreign claims of BIS-reporting banks to GDP (\%)"), the High-Income Non-OECD countries have higher values.

Table 1. Banking System in High Income Countries

\begin{tabular}{|c|c|c|c|c|}
\hline \multicolumn{5}{|l|}{ Panel A. High Income OECD Countries } \\
\hline Variable & Mean & StD & Min. & Max. \\
\hline Bank concentration $(\%)$ & 72.67 & 18.52 & 35.38 & 100.00 \\
\hline Bank deposits to GDP (\%) & 100.46 & 59.75 & 44.80 & 325.18 \\
\hline 5-bank asset concentration (\%) & 82.88 & 15.08 & 46.98 & 98.57 \\
\hline Liquid liabilities in billions 2000 USD & $1.43 \mathrm{E}+03$ & $2.78 \mathrm{E}+03$ & $9.84 \mathrm{E}+00$ & $1.11 \mathrm{E}+04$ \\
\hline Loans from non-resident banks (net) to GDP (\%) & -0.78 & 5.35 & -26.76 & 5.76 \\
\hline Loans from non-resident banks (amounts out.) to GDP (\%) & 80.63 & 198.37 & 6.96 & $1,101.34$ \\
\hline Offshore bank deposits to domestic bank deposits (\%) & 35.72 & 51.38 & 4.02 & 253.45 \\
\hline Remittance inflows to GDP (\%) & 0.75 & 0.74 & 0.04 & 2.94 \\
\hline Consolidated for. claims of BIS-reporting banks to GDP (\%) & 76.10 & 50.60 & 8.69 & 263.20 \\
\hline \multicolumn{5}{|l|}{ Panel B. High Income Non-OECD Countries } \\
\hline Variable & Mean & StD & Min. & Max. \\
\hline Bank concentration $(\%)$ & 81.95 & 14.94 & 55.32 & 100.00 \\
\hline Bank deposits to GDP (\%) & 92.43 & 82.82 & 9.33 & 301.63 \\
\hline 5-bank asset concentration (\%) & 93.43 & 9.48 & 76.27 & 100.00 \\
\hline Liquid liabilities in billions 2000 USD & 102.01 & 165.24 & 1.36 & 630.20 \\
\hline Loans from non-resident banks (net) to GDP (\%) & 0.91 & 1.09 & -0.03 & 2.87 \\
\hline Loans from non-resident banks (amounts out.) to GDP (\%) & 482.41 & $1,494.21$ & 0.19 & $6,060.98$ \\
\hline Offshore bank deposits to domestic bank deposits (\%) & 647.07 & $2,229.98$ & 4.33 & $8,393.59$ \\
\hline Remittance inflows to GDP (\%) & 0.65 & 0.84 & 0.04 & 2.22 \\
\hline Consolidated for. claims of BIS-reporting banks to GDP (\%) & 129.06 & 153.45 & 2.65 & 603.77 \\
\hline
\end{tabular}

Source: compiled by the author.

Table 2 shows the results of the Mann-Whitney-Wilcoxon tests that compare the "banking system" variables in High-Income OECD countries and the High-Income Non-OECD countries.

Table 2. Banking System in High Income OECD vs. Non-OECD Countries

\begin{tabular}{|l|c|c|c|}
\hline \multicolumn{1}{|c|}{ Variable } & OECD & Non-OECD & p-value \\
\hline Bank concentration (\%) & 72.67 & $\mathbf{8 1 . 9 5}$ & 0.0567 \\
\hline Bank deposits to GDP (\%) & $\mathbf{1 0 0 . 4 6}$ & 92.43 & 0.0782 \\
\hline 5-bank asset concentration (\%) & 82.88 & $\mathbf{9 3 . 4 3}$ & 0.0011 \\
\hline Liquid liabilities in billions 2000 USD & $\mathbf{1 , 4 3 0 . 0 0}$ & 102.01 & 0.0002 \\
\hline Loans from non-resident banks (net) to GDP (\%) & -0.78 & $\mathbf{0 . 9 1}$ & 0.0112 \\
\hline Loans from non-resident banks (amounts out.) to GDP (\%) & 80.63 & 482.41 & 0.2706 \\
\hline Offshore bank deposits to domestic bank deposits (\%) & 35.72 & $\mathbf{6 4 7 . 0 7}$ & 0.0315 \\
\hline Remittance inflows to GDP (\%) & 0.75 & 0.65 & 0.2221 \\
\hline Consolidated for. claims of BIS-reporting banks to GDP (\%) & 76.10 & 129.06 & 0.4868 \\
\hline
\end{tabular}

Source: compiled by the author.

Table 2 shows that, in terms of two measures, namely "Bank deposits to GDP (\%)" and "Liquid liabilities in billions 2000 USD", the High-Income OECD countries have significantly higher values compared to the HighIncome Non-OECD countries. While the mean value of "Bank deposits to GDP (\%)" is $100.46 \%$ for HighIncome OECD countries, the corresponding value is $92.43 \%$ for High-Income Non-OECD countries (p-value 
of the difference=0.0782). Similarly, while the mean value of "Liquid liabilities in billions 2000 USD" is 1,430.00 for High-Income OECD countries, the corresponding value is 102.01 for High-Income Non-OECD countries ( $\mathrm{p}$-value of the difference $=0.0002$ ). These results show that banks in High-Income OECD countries collect more deposits when compared to banks in High-Income Non-OECD countries. So, we can argue that they are doing much better than their counterparts in Non-OECD countries in this measure. The results here also show that banks in High-Income OECD countries are in a riskier position compared to their counterparts in High-Income Non-OECD countries because they have significantly higher short-term (or liquid) liabilities.

When we look at the table, we are seeing that in four "banking system" measures, High-Income Non-OECD countries have significantly higher values when compared to High-Income OECD countries. In terms of "Bank concentration (\%)" and "5-bank asset concentration", we are seeing that High-Income Non-OECD countries have significantly higher values. This means that the banking industries in these countries are much more concentrated when compared to their counterparts in High-Income OECD countries. The mean value of "Bank concentration (\%)" is $72.67 \%$ in High-Income OECD countries, while the corresponding value is $81.95 \%$ in High-Income Non-OECD countries (p-value of the difference=0.0567). Similarly, while the mean value of "5bank asset concentration" is 82.88 in High-Income OECD countries, the corresponding value is $93.43 \%$ in High-Income Non-OECD countries ( $\mathrm{p}$-value of the difference $=0.0011$ ).

High-Income Non-OECD countries also have significantly higher values for "Loans from non-resident banks (net) to GDP (\%)" measure. While the mean value of this measure is $-0.78 \%$ for High-Income OECD countries, the corresponding value is $0.91 \%$ for High-Income Non-OECD countries ( $\mathrm{p}$-value of the difference $=0.0112$ ). This result indicates that, in High-Income Non-OECD countries, non-resident banks are more active.

High-Income Non-OECD countries also have significantly higher values for "Offshore bank deposits to domestic bank deposits (\%)" measure. While the mean value of this measure is $35.72 \%$ for High-Income OECD countries, the corresponding value is $647.07 \%$ for High-Income Non-OECD countries ( $\mathrm{p}$-value of the difference $=0.0315$ ). This result indicates that, in High-Income Non-OECD countries, there is more interest in offshore accounts. It also indicates that the governments in these countries are more open to this type of transactions. When we look at the table, we are seeing that in terms of three measures, the two groups are not significantly different. The two groups have similar values in "Loans from non-resident banks (amounts out.) to GDP (\%)", "Remittance inflows to GDP (\%)", and "Consolidated foreign claims of BIS-reporting banks to GDP (\%)".

Table 3-Panel A shows the summary statistics for the Low-Income Countries. Table 3-Panel B shows the summary statistics for the Middle-Income Countries.

Table 3. Banking System in Low and Middle Income Countries

\begin{tabular}{|c|c|c|c|c|}
\hline \multicolumn{5}{|l|}{ Panel A. Low Income Countries } \\
\hline Variable & Mean & StD & Min. & Max. \\
\hline Bank concentration $(\%)$ & 73.12 & 23.19 & 27.07 & 100.00 \\
\hline Bank deposits to GDP (\%) & 26.70 & 12.55 & 6.57 & 58.68 \\
\hline 5-bank asset concentration (\%) & 80.02 & 20.46 & 40.91 & 100.00 \\
\hline Liquid liabilities in billions 2000 USD & 64.25 & 316.43 & 0.15 & $1,678.06$ \\
\hline \multicolumn{5}{|l|}{ Loans from non-resident banks (net) to GDP (\%) } \\
\hline Loans from non-resident banks (amounts out.) to GDP (\%) & 55.09 & 291.41 & 0.11 & $1,651.93$ \\
\hline Offshore bank deposits to domestic bank deposits (\%) & 28.84 & 33.85 & 2.04 & 143.55 \\
\hline Remittance inflows to GDP (\%) & 8.34 & 11.55 & 0.31 & 46.91 \\
\hline Consolidated for. claims of BIS-repor. banks to GDP (\%) & 5.98 & 7.89 & 0.42 & 41.55 \\
\hline \multicolumn{5}{|l|}{ Panel B. Middle Income Countries } \\
\hline Variable & Mean & StD & Min. & Max. \\
\hline Bank concentration $(\%)$ & 65.05 & 19.30 & 29.37 & 100.00 \\
\hline Bank deposits to GDP (\%) & 46.82 & 29.73 & 4.83 & 199.71 \\
\hline 5-bank asset concentration (\%) & 78.42 & 15.69 & 40.15 & 100.00 \\
\hline Liquid liabilities in billions 2000 USD & 175.4 & $1,070.5$ & 0.06 & $10,400.0$ \\
\hline Loans from non-resident banks (net) to GDP (\%) & 0.67 & 1.79 & -2.98 & 6.60 \\
\hline Loans from non-resident banks (amounts out.) to GDP (\%) & 28.02 & 76.91 & 0.60 & 573.12 \\
\hline Offshore bank deposits to domestic bank deposits (\%) & 27.37 & 40.48 & 0.54 & 330.07 \\
\hline Remittance inflows to GDP (\%) & 5.37 & 6.04 & 0.00 & 26.76 \\
\hline Consolidated for. claims of BIS-repor. banks to GDP (\%) & 38.83 & 77.04 & 0.17 & 626.10 \\
\hline
\end{tabular}

Source: compiled by the author. 
Table 4 shows the results of the Mann-Whitney-Wilcoxon tests that compare the "banking system" variables in High-Income countries (i.e. including OECD and Non-OECD countries) and the Other countries (which includes Low- and Middle-Income countries).

Table 4. Banking System in High-Income vs. Other Countries

\begin{tabular}{|c|c|c|c|}
\hline Variable & High-Income & Other & p-value \\
\hline Bank concentration $(\%)$ & 75.83 & 66.85 & 0.0077 \\
\hline Bank deposits to GDP (\%) & 97.59 & 42.48 & $<0.0001$ \\
\hline 5-bank asset concentration (\%) & 86.32 & 78.70 & 0.0078 \\
\hline Liquid liabilities in billions 2000 USD & 933.0 & 150.3 & $<0.0001$ \\
\hline Loans from non-resident banks (net) to GDP (\%) & -0.37 & 0.67 & 0.2308 \\
\hline Loans from non-resident banks (amounts out.) to GDP (\%) & 220.38 & 34.73 & $<0.0001$ \\
\hline Offshore bank deposits to domestic bank deposits (\%) & 255.18 & 27.70 & 0.0190 \\
\hline Remittance inflows to GDP (\%) & 0.72 & 6.01 & $<0.0001$ \\
\hline Consolidated for. claims of BIS-repor. banks to GDP (\%) & 95.26 & 31.01 & $<0.0001$ \\
\hline
\end{tabular}

Source: compiled by the author.

The table shows that the Other countries (i.e. the Low- and Middle-Income countries) have significantly higher values in only one measure. In these countries, "Remittance inflows to GDP (\%)" is significantly higher when compared to the High-Income countries. Workers' remittances are much higher in these countries.

In almost all other measures, the High-Income OECD countries have significantly higher values. The banking industries are much more concentrated in High-Income OECD countries as shown by the variables "Bank concentration (\%)" and "5-bank asset concentration (\%)". Bank deposits are also significantly higher in these countries as shown by the variable "Bank deposits to GDP (\%)".

The banking systems in High-Income OECD countries have more risk compared to their counterparts in HighIncome Non-OECD countries as evidenced by the variable "Liquid liabilities in billions 2000 USD".

Loans from non-resident banks are much higher in High-Income OECD countries. This result indicates that, in High-Income countries, non-resident banks are more active.

High-Income countries also have significantly higher values for "Offshore bank deposits to domestic bank deposits (\%)" measure. This result indicates that, in High-Income countries, there is more interest in offshore accounts. It also indicates that the governments in these countries are more open to this type of transactions.

High-Income countries have higher values for "Consolidated for. claims of BIS-repor. banks divided by GDP (\%)" measure. This result indicates that, in High-Income countries, banks are more engaged in international transactions.

\section{Conclusion}

In this study, we explore two issues. First, we look at the relation between countries' income levels and their "banking systems". Then, we look at how OECD membership affects the banking system of a country.

We look into nine measures of "banking system". These measures are "Bank concentration (\%)", "Bank deposits to GDP (\%)", "5-bank asset concentration (\%)", "Liquid liabilities in billions 2000 USD", "Loans from non-resident banks (net) to GDP (\%)", "Loans from non-resident banks (amounts out.) to GDP (\%)", "Offshore bank deposits to domestic bank deposits (\%)", "Remittance inflows to GDP (\%)", and "Consolidated foreign claims of BIS-reporting banks to GDP (\%)". The data on these variables are collected from World Bank's Global Financial Development Database (GFDD).

When we compare High-Income countries to Middle- and Low-Income countries, we find that workers' remittances are much higher in Low- and Middle-income countries. The banking industries are much more concentrated in High-Income countries. Bank deposits are also significantly higher in these countries. The banking systems in these countries have more risk compared to their counterparts in other countries. Nonresident banks are more active in High-Income countries. Also, there is more interest in offshore accounts and the banks are more engaged in international transactions.

When we compare high-income OECD-member countries to high-income Non-OECD-member countries, we find that the banking industries in high-income Non-OECD-member countries are much more concentrated when compared to their counterparts in High-Income OECD countries. In High-Income Non-OECD countries, non-resident banks are more active and there is more interest in offshore accounts. On the other hand, bank 
deposits are higher in High-Income OECD countries. But, the banks in these countries are in greater risk compared to the banks in Non-OECD countries (i.e. liquid liabilities are higher).

Our results indicate that policymakers need to consider OECD membership and income level as determinants of a country's banking system. Also, any study that examines a country's banking system should control for income-level and OECD membership.

\section{References}

1. Ali, M. S., Intissar, T. and Zeitun, R. (2015). Banking Concentration and Financial Stability: Evidence from Developed and Developing Countries. Economics, 1-17. Retrieved from: https://www.econstor.eu/bitstream/10419/109217/1/822199831.pdf

2. Ang, J.B. and McKibbin, W.J. (2007). Financial liberalization, financial sector development and growth: evidence from Malaysia. Journal of development economics, 84(1), 215-233. Retrieved from: https://www.sciencedirect.com/science/article/abs/pii/S0304387806001982

3. Arestis, P. and Demetriades, P. (1997). Financial development and economic growth: assessing the evidence. The economic journal, 107(442), 783-799. Retrieved from: https://academic.oup.com/ej/articleabstract/107/442/783/5057710

4. Arestis, P. and Demetriades, P. (1999). Finance and growth: Institutional considerations, financial policies and causality. Zagreb International Review of Economics \& Business, 2(1), 37-62. Retrieved from: https://hrcak.srce.hr/34394

5. Bagehot, W. (1873). Lombard Street: A description of the money market. Scribner, Armstrong \& Company. Retrieved from: https://fraser.stlouisfed.org/files/docs/meltzer/baglom62.pdf

6. Chandavarkar, A. (1992). Of finance and development: neglected and unsettled questions. World development, 20(1), 133-142. Retrieved from: https://www.sciencedirect.com/science/article/ abs/pii/0305750X9290142I

7. Demetriades, P. and Hussein, K. (1996). Financial Development and Economic Growth: Cointegration and Causality Tests for 16 Countries. Journal of Development Economics, 51, 387-411. Retrieved from: http://www.opengrey.eu/item/display/10068/437104

8. Demirguc-Kunt, A. and Detragiache, E. (1998). The Determinants of Banking Crises in Developing and Developed Countries. Palgrave Macmillan Journals, 81-109. Retrieved from: https://www.jstor.org/stable/pdf/3867330.pdf?casa token=jxzllM5pIPUAAAAA:KQNBvRL0R i4uU Xw0DkGSuU2aSI97ht1T2VHaHkG56Lt46uFZERw06YRSeZQ4PiYwo2XmDAT6j130TGhSqiQARvR nenvj82cLpxuMNCDoltY7QJ

9. Duke, A. and Cejnar, L. (2013). Competition and the banking sector: friend or foe? Law and Financial Markets Review, 152-158. https://doi.org/10.5235/17521440.7.3.152

10. Feldmann, H. (2006). Credit Market Regulation and Labor Market Performance Around the World. Oxford: Blackwell Publishing Ltd. Retrieved from: https://onlinelibrary.wiley.com/doi/abs/ 10.1111/j.1467-6435.2006.00347.x

11. Foer, A.A. and Resnikoff, D.A. (2014). Competition Policy and "too big" banks in the European Union and the United States. The Antitrust Bulletin, 9-30. Retrieved from: https://heinonline.org/HOL/Page?handle=hein.journals/antibull59\&div $=5 \& g$ sent $=1 \&$ casa token $=W 7 \mathrm{~F}$ 2 ofAwIYAAAAA:FqW1AwzpHT1toPIDRpMVGu7wg0USpdVwHlysv301-

XYDxSuXmwDMuXOexMilrUOPZd7xapA\&collection=journals

12. Fry, M.J. (1988). Money, Interest, and Banking in Economic Development. Johns Hopkins University Press, Johns Hopkins Studies in Development series Baltimore and London. Retrieved from: https://agris.fao.org/agris-search/search.do?recordID=US201300311103

13. Goldsmith, R.W. (1969). Financial structure and development (No. HG174 G57). Retrieved from: http://www.sidalc.net/cgi-bin/wxis.exe/?IsisScript=bac. $x i s \& m e t h o d=$ post\&formato $=2 \&$ cantidad $=$ 1 \&expresion $=\mathrm{mfn}=036665$

14. Haouat, M., Moccero, D. N. and Navarro, R. S. (2012). Foreign Banks and Credit Volatility: The Case of Latin American Countries. Review of International Economics, 1017-1033. Retrieved from: https://www.econstor.eu/bitstream/10419/54102/1/636594270.pdf

15. Hicks, J.R. (1969). A theory of economic history. OUP Catalogue. Retrieved from: https://pdfs.semanticscholar.org/1b3d/6285f009a71f9da22447a59174110bb4ac36.pdf 
16. King, R.G. and Levine, R. (1993). Finance and growth: Schumpeter might be right. The quarterly journal of economics, 108(3), 717-737. Retrieved from: https://pdfs.semanticscholar.org/e711/ b61ec85cd2b09d43a6737abe94035fa0e652.pdf

17. Klein, M.W. and Olivei, G.P. (2008). Capital account liberalization, financial depth, and economic growth. Journal of international money and finance, 27(6), 861-875. Retrieved from: https://www.nber.org/system/files/ working_papers/w7384/w7384.pdf

18. Kokkoris, I. (2014). Competition vs. financial stability in the aftermath of the crisis in the UK. The Antitrust Bulletin, 31-53. Retrieved from: https://journals.sagepub.com/doi/abs/10.1177/0003603 $\underline{X 1405900103}$

19. Levine, R. (1999). Financial development and economic growth: views and agenda. The World Bank. Retrieved from: https://www.researchgate.net/profile/Ross_Levine/publication/4722931_Financial Development And Economic Growth_Views And Agenda/links/0046352065300861d3000000.pdf

20. Lucas Jr, R.E. (1988). On the mechanics of economic development. Journal of monetary economics, 22(1), 3-42. Retrieved from: https://www.sciencedirect.com/science/article/abs/pii/0304393288901687

21. Odhiambo, N.M. (2008). Financial depth, savings and economic growth in Kenya: A dynamic causal linkage. Economic Modelling, 25(4), 704-713. Retrieved from: https://www.sciencedirect.com/ science/article/abs/pii/S0264999307001204

22. Pagano, M. (1993). Financial markets and growth: an overview. European Economic Review, 37, $613-$ 622. Retrieved from: https:/www.sciencedirect.com/science/article/pii/001429219390051B

23. Shaw, E.S. (1973). Financial Deepening in Economic Development. Oxford University Press, New York. Retrieved from: https://agris.fao.org/agris-search/search.do?recordID=XF2015011329

24. Stern, N., 1989. The economics of development: a survey. The Economic Journal, 99(397), 597-685. Retrieved from: https://personal.lse.ac.uk/sternn/048NHS.pdf 